\title{
ANTIOXIDANT ACTIVITY, ANTHOCYANINS AND ORGANIC ACIDS CONTENT OF GRAPE JUICES PRODUCED IN SOUTHWEST OF MINAS GERAIS，BRAZIL
}

\author{
Atividade antioxidante, antocianinas e teor de ácidos orgânicos de sucos de \\ uva produzidos no sudoeste de Minas Gerais, Brasil
}

\author{
Ana Carolina Vilas Boas ${ }^{1}$, Paôla de Castro Henrique ${ }^{2}$, \\ Luiz Carlos de Oliveira Lima ${ }^{2}$, Antônio Decarlos Neto ${ }^{3}$
}

\begin{abstract}
Phenolic compounds and anthocyanins content in grape juices varies in the cultivar, ripening and climate characteristics. The objective of this work was to characterize and evaluate antioxidant activity of grape juices produced in southwestern Minas Gerais. Grapes were harvested, sanitized and the juices from cultivars 'Bordô', 'Isabel Precoce', 'BRS Violeta' and 'BRS Rúbea' were produced in artisanal equipment by steam extraction and stored for 120 days. The following analyzes were performed during storage: color $\left(\mathrm{L}^{*}\right), \mathrm{pH}$, soluble solids, titratable acidity, anthocyanins, antioxidant activity (DPPH and $\beta$-caroteno/linoleic acid), total phenolics, vitamin $\mathrm{C}$ and organic acids. Among the cultivars evaluated, the consumption of grape juice from cultivar 'BRS Violeta' is suggested due to its higher content of vitamin C, antioxidant activity, total phenolics, anthocyanins, and also due to a better physicochemical characteristic showed, when compared to the juices of the other cultivars.
\end{abstract}

Index terms: Vitis labrusca, phenolics, vitamin $\mathrm{C}$, organic acids.

\begin{abstract}
RESUMO
O teor de compostos fenólicos e antocianinas em sucos de uva varia de acordo com a cultivar, maturidade e características climáticas. Neste trabalho, objetivou-se a caracterização e a avaliação da atividade antioxidante de sucos de uvas americanas produzidas no sudoeste de Minas Gerais. As uvas foram colhidas, sanitizadas, sendo as grainhas e demais partes dos cachos descartadas. Então, os sucos das cultivares Bordô (Vitis labrusca), Isabel Precoce (Vitis labrusca), BRS Violeta (híbrida) e BRS Rúbea (híbrida) foram produzidos em equipamento artesanal por extração em vapor de água, acondicionados em frascos de vidro e armazenados a $18^{\circ} \mathrm{C} \pm 2^{\circ} \mathrm{C}$ por 120 dias. As seguintes análises foram realizadas ao longo do armazenamento: cor ( $\left.\mathrm{L}^{*}\right)$, pH, sólidos solúveis totais, acidez titulável, , antocianinas, atividade antioxidante (DPPH e $\beta$-caroteno/ácido linoléico), fenólicos totais, vitamina C e ácidos orgânicos. Entre as cultivares avaliadas, sugere-se o consumo do suco de uva da cultivar BRS Violeta, pelos maiores valores de vitamina $\mathrm{C}$, atividade antioxidante, fenólicos totais, antocianinas, além de apresentar melhores características físico-químicas quando comparada ao suco das demais cultivares.
\end{abstract}

Termos para indexação: Vitis labrusca, fenólicos, vitamina C, ácidos orgânicos.

\section{INTRODUCTION}

Studies have reported an inverse relationship between the consumption of fruits and vegetables and mortality due to age-related diseases. This can be attributed in part to the presence of antioxidants, especially phenolic compounds in the diet (Dudonné et al., 2009). Consumption of grape juice is associated with several health benefits effects such as increasing of the antioxidant capacity, improvement of endothelial function, inhibition of platelet aggregation, reduction of plasma proteins oxidation, reduction of low density lipoproteins (LDL) and improvement of cardiovascular oxidation and neurocognitive function (Krikorian et al., 2012; Evans; Wilson; Guthrie, 2014; Tenore et al., 2012). Grape juices are known to have a very high content of phenolic compounds and depending on their chemical structure, they are divided into several classes that are directly responsible for special characteristics of grapes and their derivatives (Mattivi et al., 2006; Rodríguez Montealegre et al., 2006). In addition to the functional properties, phenolic compounds present in grape juice may also contribute to define sensory characteristics of this product (Recamales, 2006).

Grape juice is defined as an energy drink unfermented, non-alcoholic, with characteristic color, aroma and flavor. According to legal requirements, it must

${ }^{1}$ Universidade Federal de Lavras/UFLA - Departamento de Ciência dos Alimentos/DCA - Cx. P. 3037 - $37200-000$ - Lavras - MG - Brasil vbanacarolina@yahoo.com.br

${ }^{2}$ Universidade Federal de Lavras/UFLA - Departamento de Ciência dos Alimentos/DCA - Lavras - MG - Brasil

${ }^{3}$ Universidade Federal de Lavras/UFLA - Departamento de Agricultura/DAG - Lavras - MG - Brasil

Received in april 23, 2014 and approved in july 30, 2014

Ciênc. Agrotec., Lavras, v.38, n.5, p.480-486, set./out., 2014 
be wine, pink or translucid colored, minimum soluble solids content of $14^{\circ} \mathrm{Brix}$, minimum total acidity of $0.41 \%$ and maximum of $20 \%$ of total naturally occurring sugars from the grape. If the juice is whole, it must be in its natural concentration, with no added sugar (Brasil, 2000; Brasil, 2009).

The southwestern of Minas Gerais is not traditionally known as a producing region of grapes and products derived from their processing. Thus, it is believed that the land and climate characteristics are important in the context of Brazilian viticulture, since the major grape producing regions are Rio Grande do Sul and São Francisco Valley (SFV). The southwestern Minas Gerais is located in the southeastern region of Brazil, known for a subtropical climate, with exposure of sunshine most of the year. However, the characterization of grape juices produced in this region is an unexplored area of research, since there are no reports of typicality, content of phenolic compounds, antioxidant activity, vitamins and coloring of such products.

Therefore, the aim of this study was to evaluate the antioxidant activity, phenolic compounds, anthocyanin and organic acids content of grape juices from different cultivars produced in southwestern Minas Gerais, Brazil.

\section{MATERIAL AND METHODS}

Grape juices were produced experimentally in the Enology Laboratory of the Federal University of Lavras (Lavras, MG, Brazil), using grapes from the 2012/2013 harvest, grown in the same region of southwestern of Minas Gerais in the institutional orchard. Four varieties of red grapes were used in the production of juice: 'Bordô' (Vitis labrusca), 'Isabel Precoce'(Vitis labrusca), 'BRS Violeta' (hybrid) and 'BRS Rúbea' (hybrid). After harvesting, grapes were kept in cold storage at $10^{\circ} \mathrm{C} \pm$ $2^{\circ} \mathrm{C}$ for 12 hours. Then, fruits were sanitized with sodium hypochlorite at $200 \mathrm{mg} . \mathrm{L}^{-1}$ and the seeds were removed manually. Preparation of the grape juice was performed at $75^{\circ} \mathrm{C} \pm 5^{\circ} \mathrm{C}$ for 1 hour, using an artisan equipment by drag steam according to Rizzon, Manfroi and Meneguzzo (1998). For each liter of grape juice, it was added $0.8 \mathrm{~g}$ of potassium metabisulphite (Synth ${ }^{\circledR}$, Diadema, Brazil). The potassium metabisulphite was used in order to preserve the product, to contain $\mathrm{SO}_{2}$ (sulfur dioxide), which has antimicrobial and antioxidant activity. Then, the juice was immediately bottled in glass bottles of $100 \mathrm{ml}$ and maintained under refrigeration $\left(18^{\circ} \mathrm{C} \pm 2^{\circ} \mathrm{C}\right)$ until analysis.

The following analyzes were performed on days 0 , $15,30,60$ and 120 of storage: color $\left(\mathrm{L}^{*}\right), \mathrm{pH}$, soluble solids, titratable acidity, antioxidant activity (DPPH and $\beta$-caroteno/ linoleic acid), total phenolics and vitamin C. Organic acids and anthocyanins analyses were performed on days 0 and 120 .
Color of the juices was measured using a Minolta colorimeter, model CR-400, at Comission Internacionale de Eclairage system (CIE, 1978), searching the coordinate $\mathrm{L}^{*}$. The $\mathrm{L}^{*}$ coordinate measures the lightness or brightness of the sample, ranging from black (0) to white (100). $\mathrm{pH}$ measurement was done using a pHmeter Tecnal (Tec 3M) with a glass electrode, as recommended by Association of Official Analytical Chemists (AOAC, 2007). The total soluble solids of the juices were determined using a digital refractometer ATAGO PR-100, and the results expressed as \%, according to the AOAC technique (2007). The titratable acidity was also determined by method suggested by AOAC (2007), performing titration with sodium hydroxide $(\mathrm{NaOH})$ solution 0.1 mol. $\mathrm{L}^{-1}$, and the results expressed in (\%) of tartaric acid.

Total phenolics were obtained according to colorimetric method developed by Singleton and Rossi (1965), using Folin-Ciocalteu reagent, in solution containing $10 \%(\mathrm{v} / \mathrm{v})$. The extraction procedure involved sequential steps of centrifugation, filtration and rest, in order to obtain a better extraction of phenolic compounds as described in Larrauri, Rupérez and Saura-Calixto (1997). Determination of antioxidant activity of juices was performed by DPPH (2,2-diphenyl-1-picryl-hydrazyl) method, proposed by Brand-Williams, Cuvelier and Berset (1995), adapted by Rufino et al. (2007a). For purposes of comparison with results from the literature, the percentage of free radical sequestration was calculated (\% FRS) according to equation suggested by Duarte-Almeida et al. (2006): \% FRS $=(A c-A m) \times 100 / A c$, where Ac (control absorbance) and As (sample absorbance). In this parameter, higher values indicate greater antioxidant capacity of the sample studied.

Evaluation of antioxidant activity of the juices by $\beta$-caroteno/linoleic acid system followed the protocol recommended by Miller (1971) and adapted by Rufino et al (2007b). The extract samples were obtained according to the methodology of Larrauri, Rupérez and Saura-Calixto (1997). The results were expressed in \% inhibition of the system oxidation against oxidation.

The analysis of total content of anthocyanins was performed following the method of differential $\mathrm{pH}$ proposed by Giusti and Wrolstad (2001) and the results were expressed in $\mathrm{mg} \mathrm{L}^{-1}$. The quantification of vitamin $\mathrm{C}$ was made by colorimetric method, using 2,4-dinitrophenylhydrazine according to Strohecker and Henning (1967). Reading was performed at $520 \mathrm{~nm}$ in spectrophotometer Beckman 640B, with computerized system. Results were expressed in $\mathrm{mg}$ of ascorbic acid $100 \mathrm{~mL}^{-1}$ of juice.

Organic acids content was performed by high performance liquid chromatography (CLAE) at the Center 
for Advanced Analytics and Biotechnology at Federal University of Lavras. A SHIM-PACK SPR-H (250mm $x 7.8 \mathrm{~mm}$ ) column, fitted with pre-column SHIM-PACK SPH-H (G) (50mm x 7.8) was used. As mobile phase, the following solvents were used: (A) Aqueous solution $4 \mathrm{mM} \rho$-sulfonic acid toluene and (B) Aqueous solution $16 \mathrm{mM}$ Bis-Tris, $4 \mathrm{mM} \rho$-sulfonic acid toluene and 100 $\mu \mathrm{M}$ EDTA. The flow used was $0.8 \mathrm{ml} / \mathrm{min}$, conductivity detector (DCE-6A) at temperature of $43^{\circ} \mathrm{C}$ and volume of injected sample $10 \mu \mathrm{L}$. As pre-treatment of the sample, no other process has been necessary besides filtration through a membrane filter (porosity $0.45 \mu \mathrm{m}$ ) before injection.

The experimental design was the completely randomized (CRD) in factorial ( $4 \times 5)$ consisting of four juices from different grape cultivars and five periods of storage $(0$, $15,30,60$ and 120 days), with 4 replicates. Tukey's test at $5 \%$ probability was used to compare treatments within each time. The polynomial regression models, used for storage time were selected based on the significance of the $F$ test for each model tested and the coefficient of determination.

\section{RESULTS AND DISCUSSION}

Color of grape juice is considered an important indicator of quality, usually being the first sensory attribute observed by the consumer. In addition, tonality and intensity of the color in the juice can provide information about the quality of the raw material used in its preparation. Changes in the color of the juice can be related to the grape cultivar used, as well as be influenced by the production techniques adopted (Gurak et al., 2010). Thus, figure 1 shows the values of $\mathrm{L}^{*}$ and the table 1 shows the values of monomeric anthocyanins of whole grape juices produced in Minas Gerais.

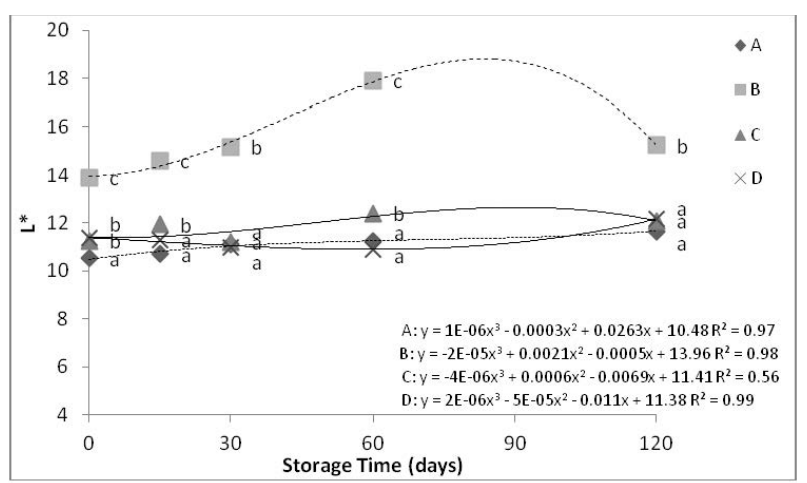

Figure 1 - Values of $L^{*}$ of grape juices produced in southwestern Minas Gerais (A: Bordo, B: Isabel Precoce, C: BRS Rubea, D: BRS Violeta)
Table 1 - Values of total anthocyanins content determined as cyanidin 3-glucoside of grape juices produced in southwestern Minas Gerais at 0 and 120 days.

\begin{tabular}{ccc}
\hline & \multicolumn{2}{c}{ Total Anthocyanins $\left(\mathrm{mg} \mathrm{L}^{-1}\right)$} \\
\hline Cultivars & \multicolumn{1}{c}{ Time 0} & Time 120 \\
\hline Bordo & $757.61 \mathrm{aB}$ & $760.15 \mathrm{aC}$ \\
Isabel Precoce & $130.88 \mathrm{aA}$ & $120.95 \mathrm{aA}$ \\
BRS Violeta & $1004.35 \mathrm{aC}$ & $859.21 \mathrm{bD}$ \\
BRS Rúbea & $769.34 \mathrm{aB}$ & $600.46 \mathrm{bB}$ \\
\hline
\end{tabular}

Lowercase letters indicate differences in row and uppercase letters in column.

It is known that anthocyanins are water-soluble plant pigments that provide color to a variety of vegetables, cereal grains, flowers and fruits such as berries. Anthocyanins belong to the flavonoid class of compounds commonly known as polyphenols. In the last two decades, interest in anthocyanins has increased due to its use as natural food colorants and their potential properties in health promotion (Andersen, 2009).

Starting from the premise that lower $\mathrm{L}^{*}$ values are closer to the black color and higher $\mathrm{L}^{*}$ values are closer to the white color, it is observed that the grape juice cultivar 'Isabel Precoce' has greater luminosity index, and the juices from the cultivars 'BRS Violeta', 'Bordô' and 'BRS Rúbea' more red, or darker. Whereas the color of the juice is given by its content of anthocyanins, it is expected that the juices from cultivars 'BRS Violeta', 'Bordô' and 'BRS Rúbea' show higher levels of anthocyanins compared to the juice from cultivar 'Isabel Precoce' (Table 1).

Moreover, it was observed that the juices from cultivars 'Bordô' and 'Isabel Precoce' did not vary significantly with respect to time, unlike the juices from cultivars 'BRS Rúbea' and 'BRS Violet', which showed lower levels of anthocyanins throughout the storage period, reaching at 120 days, 600.46 and $859.21 \mathrm{mg} \mathrm{L}^{-1}$, respectively.

Physicochemical characterization of grape juices is extremely important because it reveals aspects that make the product accepted or not by the consumer. Figure 2 shows $\mathrm{pH}$, titratable acidity and total soluble solids of grape juices produced in Minas Gerais.

We observed a downward trend in $\mathrm{pH}$ values for 'Violeta' and 'Isabel Precoce' cultivars during storage. Rizzon and Link (2006), in a comparison study with different grape cultivars, realized that cultivar 'Isabel' presents more acidic characteristics. This information confirms the $\mathrm{pH}$ value found for 'Isabel Precoce', since Ritschel and Camargo (2007) claim that the cultivar 'Isabel Precoce' presents agronomic and physicochemical characteristics very similar to the cultivar 'Isabel'. The

Ciênc. Agrotec., Lavras, v.38, n.5, p.480-486, set./out., 2014 
content of total soluble solids reflects, among other factors, the levels of sugars in the food and it suffers direct influence of the grape cultivar used. Grape juice from cultivar 'Violeta' showed a downward trend over time, in addition to having a higher content of total soluble solids when compared to the other cultivars. Values of soluble solids found in the juices of all cultivars ('Bordô', 'Isabel Precoce', 'BRS Violeta' and 'BRS Rúbea') were below the level established by the Brazilian legislation, which is $14^{\circ}$ Brix (Brasil, 1998).

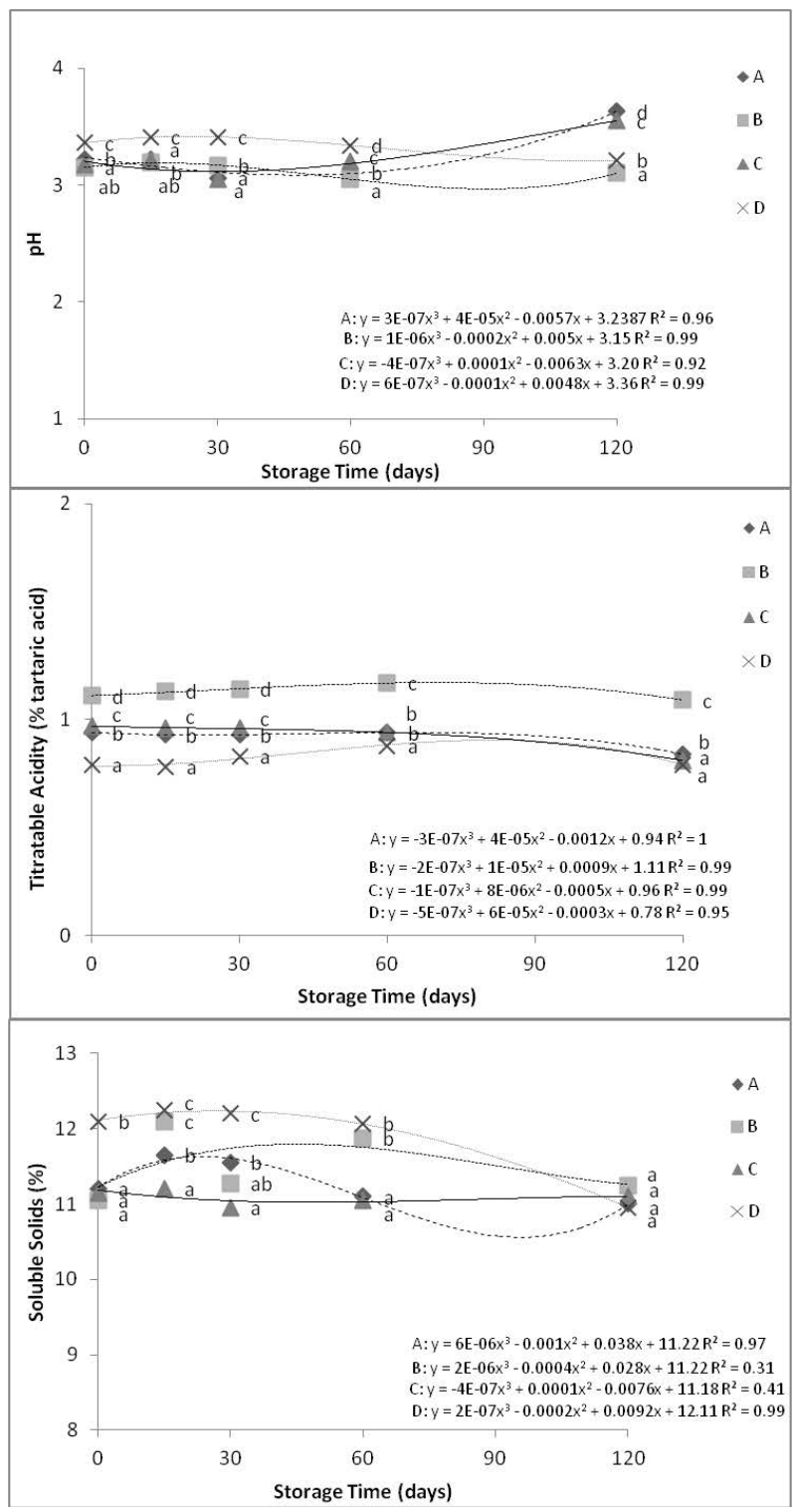

Figure $2-\mathrm{pH}$, titratable acidity and soluble solids of grape juices produced in southwestern Minas Gerais (A: Bordo, B: Isabel Precoce, C: BRS Rubea, D: BRS Violeta).
Regarding the levels of titratable acidity of grape juices, Brazilian legislation establishes a minimum of 0.419 $\mathrm{g}$ of tartaric acid in $100 \mathrm{~mL}$ of juice or $0.49 \%$ (Brasil, 1998). Thus, all the juices are suitable, being the juice from the cultivar 'Isabel Precoce', the one with highest content of titratable acidity throughout the period, with average values of $1.12 \%$ of tartaric acid. According to Girard and Mazza (1998), the presence of high levels of acidity in grape juice is justified by the organic acid content of the grapes, with a predominance of tartaric, malic and citric acids, being the distribution of these compounds variable within the grape cultivar.

Several techniques have been used to determine in vitro antioxidant activity of plant products. Among the methods used are DPPH and autoxidation of $\beta$-carotene/ linoleic acid system. Thus, antioxidant activity of different grape juices is presented in figure 3 .

Cultivar 'Isabel Precoce' showed the lowest \% FRS compared to others cultivars (Figure 3), which shows that most cultivars painties, such as the 'Violeta', have higher antioxidant activity. Vargas, Hoelzel and Rosa (2008),

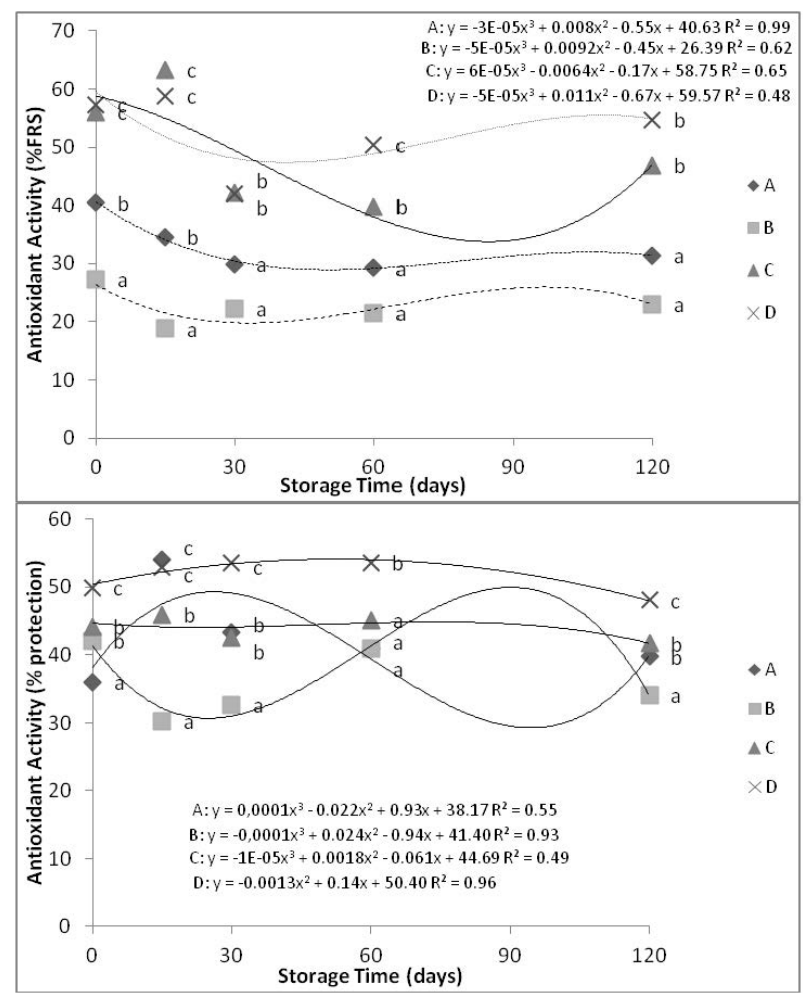

Figure 3 - Antioxidant activity by DPPH method (\% FRS) and $\beta$-carotene/linoleic acid ( $\%$ protection) of grape juice produced in Minas Gerais (A: Bordo, B: Isabel Precoce, C: BRS Rubea, D: BRS Violeta). 
working with juices of red and white grape found \% FRS ranging from $42 \%$ to $114 \%$, with the lowest values for the antioxidant activity of juices from white grapes. According to these authors, although polyphenols are the main determinants of the antioxidant activity of juices, vitamin C can also contribute to this parameter, although on a smaller scale. Grape juice from the cultivar 'Isabel Precoce' also showed less \% protection from oxidation, being the juice of the cultivar 'BRS Violeta', the one which showed the highest values during storage, reaching average of $51.61 \%$ protection.

Vitamin C appears as one of the major micronutrients in grapes and, according to Sun et al. (2002), their presence certainly contributes to the antioxidant activity of this fruit, whereas vitamin $\mathrm{C}$ is a potent antioxidant. Phenolic compounds, moreover, are a heterogeneous group of substances found in plant foods in varying concentrations, which are interesting, especially for the antioxidant potential that they have (Scalbert; Williamson, 2000). Levels of vitamin C and phenolics of grape juices from different cultivars are shown in figure 4.
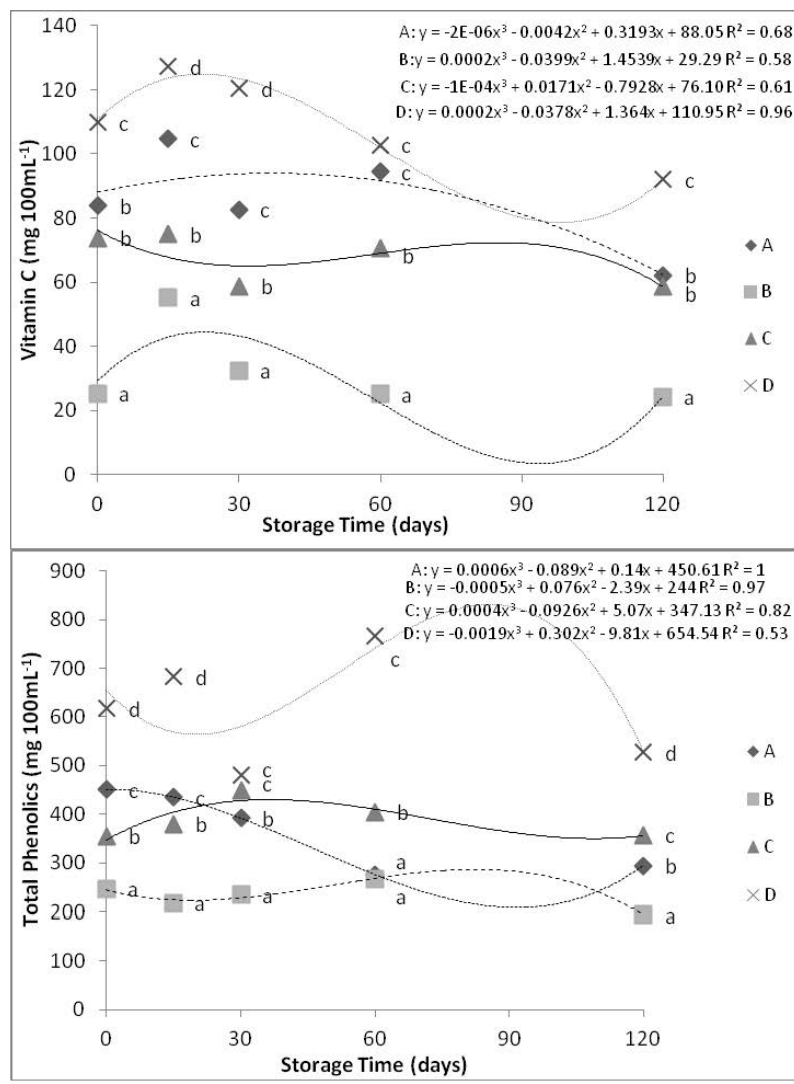

Figure 4 - Vitamin $\mathrm{C}$ and total phenolics of grape juices produced in southwestern Minas Gerais (A: Bordo, B: Isabel Precoce, C: BRS Rubea, D: BRS Violeta).
Through figure 4, we observed that grape juices differed significantly in the levels of vitamin $\mathrm{C}$, and the juice from the cultivar 'Isabel Precoce' presented lower mean values of $32.43 \mathrm{mg} 100 \mathrm{~mL}^{-1}$. Grape juices from 'BRS Violeta' showed the highest values throughout the period. Among the samples analyzed, we observed that juices from grapes 'BRS Violeta' showed the highest total phenolic contents, reaching average of $614.84 \mathrm{mg} 100 \mathrm{~mL}^{-1}$. The lowest values were observed for the cultivar 'Isabel Precoce', reaching values of $193.06 \mathrm{mg} 100 \mathrm{~mL}^{-1}$ at 120 days of storage. According to Mulero, Pardo and Zafrilla (2010), several factors may influence the concentration of phenolic compounds in juices, including the grape culitvar used. Natividade et al. (2013), evaluating the concentration and profile of phenolic compounds, also noted differences between grape cultivars used in the preparation of grape juices produced in São Francisco Valley, Brazil.

Organic acids content in grapes is influenced by a number of factors such as grape variety, degree of ripeness, growing region, level of insolation and climatic conditions. These compounds are important signals in determining the ripeness of the grape and the flavor of its derivatives (Soyer; Koca; Karadeniz, 2003). Therefore, table 2 shows the content of organic acids (tartaric acid and malic acid) of grape juices produced in southwestern Minas Gerais analyzed by HPLC.

Table 2 - Organic acids content of grape juices produced in southwestern Minas Gerais.

\begin{tabular}{cccc}
\hline & \multicolumn{2}{c}{ Tartaric acid $\left(\mathrm{g} \mathrm{L}^{-1}\right)$} & Malic acid $\left(\mathrm{g} \mathrm{L}^{-1}\right)$ \\
\hline Cultivars & Day 0 & Day 120 & Mean Values \\
\hline Bordo & $4.12 \mathrm{bB}$ & $4.82 \mathrm{bB}$ & $2.00 \mathrm{~A}$ \\
Isabel Precoce & $2.02 \mathrm{aA}$ & $2.64 \mathrm{aA}$ & $3.01 \mathrm{~A}$ \\
BRS Violeta & $2.20 \mathrm{aA}$ & $2.77 \mathrm{aA}$ & $4.35 \mathrm{~B}$ \\
BRS Rubea & $4.79 \mathrm{bC}$ & $5.27 \mathrm{bC}$ & $2.53 \mathrm{~A}$ \\
\hline
\end{tabular}

Lowercase letters indicate differences in row and uppercase letters in column.

Just as sugars, organic acids present in grape juices also contribute to its sensory quality, because they ensure a balance between sweet and acid flavors, which confers a palatability appreciated (Gurak et al., 2010). Furthermore, it is noteworthy that, although the organic acids are molecules of low molecular weight, they are able to influence various sensory characteristics such as flavor, color and aroma. They may also contribute to the stability of the juice and microbiological quality (Mato; Suárez-Luque; Huidobro, 2005, 2007). According to 
Rizzon and Link (2006) and Mato, Suárez-Luque and Huidobro (2005), in grape juice, tartaric acid and malic acid predominate, whereas citric and succinic acids are present in smaller proportions. Grape juices from cultivars 'BRS Rúbea' and 'Bordô' showed a high level of tartaric acid at 0 and 120 days of storage (Table 2), and juices from cultivar 'BRS Violeta' showed a higher content of malic acid when compared to the juice of other cultivars, not being significant in relation to the factor time.

\section{CONCLUSIONS}

Among the grape cultivars evaluated, it is suggested the consumption of grape juice from 'BRS Violeta' due to its higher antioxidant activity, higher levels of anthocyanins, phenolic compounds, vitamin $\mathrm{C}$ and malic acid content, as well as better physical and chemical characteristics.

\section{REFERENCES}

ANDERSEN Ø.M; Recent advances in the field of anthocyanins - Main focus on structures. In: F. Daayf, \& V. Lattanzio (Eds.), Recent Advances in Polyphenol Research, 1, Oxford, UK: Wiley-Blackwell, 2008, 416 p.

\section{ASSOCIATION OF OFFICIAL ANALYTICAL}

CHEMISTS, Official Methods of the Association of the Agricultural Chemists, eighteen ed. Association of Official Analytical Chemists, Gaithersburg, 2007, 1298 p.

BRAND-WILLIAMS, W.; CUVELIER M.E.; BERSET, C. Use of a free radical method to evaluate antioxidant activity. Food Science and Technology. 28(1):25-30, 1995.

BRASIL. Ministério da Agricultura. Decreto no 6871, de 04 de junho de 2009. Regulamenta a Lei $n^{\circ} 8.918$, de 14 de julho de 1994, que dispõe sobre a padronização, a classificação, o registro, a inspeção, a produção e a fiscalização de bebidas. Diário Oficial da República Federativa do Brasil, Brasília, 05 jun. 2009.

Disponível em: http://planalto.gov.br/ccivil_03? Leis/ L8918.htm> Acesso em: 25 jun 2011.

BRASIL. Instrução Normativa ${ }^{\circ} 1$, de 07 de janeiro de 2000. Aprova os regulamentos técnicos para fixação dos padrões de identidade para polpa e suco de fruta, conforme costa no anexo II desta instrução normativa. Diário Oficial da República Federativa do Brasil, Brasília, 10 jan. 2000. Seção 1, p.5-58.
BRASIL. Ministério da Agricultura. Portaria no. 544 de 16 de novembro de 1998. Aprova o Regulamento Técnico para Fixação dos Padrões de Identidade e Qualidade para Refresco. Diário Oficial da República Federativa do Brasil, Brasília, 10 nov. 1998. Disponível em: $<$ http://oc4j.agricultura.gov.br/agrolegis/ $\mathrm{do} / \mathrm{consultaLei}$ op $=$ viewTextual\&codigo $=1150>$.

Acesso em: 30 abr 2010.

COMISSION INTERNATIONALE DE I'ECLAIRAGE. Recommendations on uniform color spaces-color difference equations, psychomettic color terms. Paris: CIE, 1978, 21p.

DUARTE-ALMEIDA, J.M. et al. Avaliação da atividade antioxidante utilizando sistema $\beta$-caroteno/ácido linoléico e método de seqüestro de radicais DPPH. Ciência e Tecnologia de Alimentos. 26(2):446-452, 2006.

DUDONNÉ, S. et al. Comparative study of antioxidant properties and total phenolic content of 30 plant extracts of industrial interest using DPPH, ABTS, FRAP, SOD, and ORAC assays. Journal of Agricultural and Food Chemistry. 57(5):1768-1774, 2009.

EVANS, M.; WILSON, D.; GUTHRIE, N. A randomized, double-blind, placebo controlled,pilot study to evaluate the effect of whole grape extract on antioxidant status and lipid profile. Journal of Functional Foods. 7(1):680-691, 2014.

GIRARD, B.; MAZZA, G. Produtos funcionales derivados de lã uvas y de lós cítricos. In: Mazza, G.; Acribia, S.A. Alimentos funcionales: aspectos bioquímicos e de procesado. Zaragoza: Acribia, cap. 5, p.141-182, 1998.

GIUSTI, M.M.; WROLSTAD, R.E. Anthocyanins: characterization and measurement with uv-visible spectroscopy. In: WROLSTAD, RE, Current protocols in food analytical chemistry, cap. 1, p.1-13, 2001.

GURAK, P.D. et al. Quality evaluation of grape juice concentrated by reverse osmosis. Journal of Food Engineering. 96(3):421-426, 2010.

KRIKORIAN, R. et al. Concord grape juice supplementation and neurocognitive function in human aging, Journal of Agricultural and Food Chemistry. 60(23):5736-5742, 2012. 
LARRAURI, J.A.; RUPÉREZ, P.; SAURA-CALIXTO, F. Effect of drying temperature on the stabilitity of polyphenols and antioxidant activity of red grape pomace peels. Journal of Agricultural and Food Chemistry. 45(4):1390-1393, 1997.

MATTIVI, F. et al. Metabolite profiling of grape: flavonols and anthocyanins. Journal of Agricultural and Food Chemistry. 54(20):7692-7702, 2006.

MATO, I.; SUÁREZ-LUQUE, S.; HUIDOBRO, J.F. A review of the analytical methods to determine organic acids in grape juices and wines. Food Research International. 38(10):1175-1188, 2005.

MATO, I.; SUÁREZ-LUQUE, S.; HUIDOBRO, J.F. Simple determination of main organic acids in grape juice and wine by using capillary zone electrophoresis with direct UV detection. Food Chemistry. 102(1):104-112, 2007.

MILLER, H.E. A simplified method for the evaluation of antioxidant. Journal of the American Oil Chemists Society. 48(2):91-97, 1971.

MULERO, J.; PARDO, F.; ZAFRILLA, P. Antioxidant activity and phenolic composition of organic and conventional grapes and wines, Journal of Food Composition and Analysis. 23(6):569-574, 2010.

NATIVIDADE, M.M.P. et al. Simultaneous analysis of 25 phenolic compounds in grape juice for HPLC: Method validation and characterization of São Francisco Valley samples. Microchemical Journal. 110:665-674, 2013.

RECAMALES, A.F. et al. The effect of time and storage conditions on the phenolic composition and colour of white wine, Food Research International. 39(2):220229, 2006.

RITSCHEL, P.; CAMARGO, U.A. O programa de melhoramento de uva e o segmento de sucos. Bento Gonçalves: Embrapa Uva e Vinho, 2007.

RIZZON, L.A.; MANFROI, V.; MENEGUZZO, J. Elaboração de suco de uva na propriedade vitícola, Embrapa Uva e Vinho Bento Gonçalves, 1998, 24 p.

RIZZON, L.A.; LINK, M. Composição do suco de uva caseiro de diferentes cultivares. Ciência Rural. 36:689$692,2006$.
RODRÍGUEZ MO, R. et al. Phenolic compounds in skins and seeds of ten grape Vitis vinifera varieties grown in a warm climate. Journal of Food Composition and Analysis. 19(6):687-693, 2006.

RUFINO, M.S.M. et al. Metodologia científica: determinação da atividade antioxidante total em frutas pela captura do radical livre DPPH. Fortaleza: Embrapa, 4p. (Comunicado técnico, 127), 2007a

RUFINO, M.S.M. et al. Metodologia científica: determinação da atividade antioxidante total em frutas no sistema $\boldsymbol{\beta}$ caroteno - ácido linoléico. Fortaleza: Embrapa, 4p. (Comunicado técnico, 126), $2007 b$.

SCALBERT, A.; WILLIAMSON, G. Dietary intake and bioavailability of polyphenols. Journal of Nutrition.130(8):2073-2085, 2000.

SINGLETON, V.L.; ROSSI, J.A. Colorimetry of total phenolics with phosphomolybdic-phosphotungstic acid reagents. American Journal of Enology and Viticulture. 16(3):144-158, 1965.

SOYER, Y.; KOCA, N.; KARADENIZ, F. Organic acid profile of Turkish white grapes and grape juices. Journal of Food Composition and Analysis. 16(5):629-636, 2003.

STROECKHER, R.; HENNING, H.M. Analisis de vitaminas: metodos comprobados. Madrid: Paz Montalvo, 428p., 1967.

SUN, J. et al. Antioxidant and antiproliferative activities of common fruits. Journal of Agricultural and Food Chemistry. 50(25):74497454, 2002.

TENORE, G.C. et al. Antioxidant profile and in vitro cardiac radical-scavenging versus pro-oxidant effects of commercial red grape juices (Vitis vinifera L. cv. Aglianico N.) Journal of Agricultural and Food Chemistry. 60(38):9680-9687, 2012.

VARGAS, P.N.; HOELZEL, S.C.; ROSA, C.S. Determinação do teor de polifenóis totais e atividade antioxidante em sucos de uva comerciais, Araraquara, Alimentos e Nutrição.19(1):11-15, 2008. 